\title{
Fishermen fight rangers in conservation battle for Galápagos
}

[MUNICH] Violence has broken out in the once tranquil Galápagos Archipelago as tensions intensify between illegal fishermen and conservationists intensify.

In the most serious incident, fishermen opened fire last month on park rangers who had found their illegal camp, seriously wounding one of them. In other incidents, park rangers, local politicians and the captain of a patrol boat have been attacked with cudgels and bottles, and threatened with death.

The islands have appealed to the government of Ecuador, to which they belong, for support from the navy to protect staff. Robert Bensted-Smith, director of the islands' Charles Darwin Research Station, says that the violence, though serious, "is confined to a small, hard-core group of fishermen who are taking an aggressive stand".

The Ecuadorian islands retain 90 per cent of the biodiversity that was observed by Charles Darwin when he visited them in 1835. But although they have been designated as a national park, and listed as a
World Heritage Site by the United Nations Educational, Scientific, and Cultural Organization (UNESCO), management of their ecological resources has become increasingly difficult.

Their waters, including the supposedly protected marine reserve, have been seriously overfished in recent years. Limited fishing quotas, and the total ban on the fishing of the sea cucumber, Isostichopus fuscus, a coveted delicacy in Asia that is threatened with extinction (see Nature 383, 3 ; 1996), continue to be ignored.

The fishermen pose a serious threat to the biodiversity of the world's most valuable ecological resource, not only by depleting it of important marine species, but also by introducing new species such as rats and innumerable insects which upset the archipelago's ecological balance.

The islands are also threatened by increased immigration from poorer provinces of Ecuador. A controversial bill introduced by a local politician last year would have controlled this immigration, but would have allowed immigrants a level of agricultural activity that conservationists believed would also threaten the ecological balance. The bill was abandoned when the shaky Ecuadorian government fell earlier this year, and the new government has set up a committee to redraft it. Bensted-Smith is optimistic that the new version, which the government hopes to present to parliament in June, will be more favourable to conservationists.

This is partly because the conservationists' cause now has an additional, and powerful, political weapon, he says. UNESCO's World Heritage Committee last December placed the Galápagos Islands on its list of World Heritage Sites in Danger. This means that the Ecuadorian government has until November to offer persuasive arguments that it will be able to contain the threats to the islands' biodiversity.

If it does not, UNESCO will strip the islands of their status as a World Heritage Site, a move that would inevitably damage the tourism upon which the Galápagos' new-found wealth depends.

Alison Abbott

\section{'Ark evidence' challenged in Sydney court}

[SYDNEY] It was hard to find standing room inside Federal Court 23C as the now worldfamous 'Noah's Ark/Creationism Trial' opened in Sydney, Australia, last week.

Ian Plimer, a geologist at the University of Melbourne, and David Fasold, former marine salvager of Oregon in the United States, are alleging that Allen Roberts engaged in misleading and deceptive commercial conduct and breach of copyright. In 1992, Roberts, a Bible Church elder and selfstyled historian and archaeologist of Sydney, claimed to have "scientific" evidence for the remains of Noah's Ark in Turkey and raised funds for an "expedition" (see Nature 386, 529; 1997).

Early attempts to confine the court proceedings to commercial aspects were eroded as Plimer wove into evidence statements on academic standards and responsibility, and the methods and philosophy of science. Judge Ronald Sackville, former dean of law at the University of New South Wales, intervened to clarify each of these areas on the record. A judgement, however, can be made only under laws on trade practices and copyright.

When asked about Roberts' doctorate in Christian education from Freedom University, a correspondence Bible college that moves around Florida and which Roberts admits is not accredited, Plimer said: "I would not have the gall to display it behind my name and call myself an educator."

Alex Radojev, senior counsel for Roberts, probed Plimer's knowl-

IMAGE

UNAVAILABLE

FOR

COPYRIGHT

REASONS edge of the alleged Ark site and queried the "credit" of his motives in bringing the case. Plimer responded that he was "affronted" by each of Roberts' claims of "eviFasold: believer dence" for the Ark as turned critic. being unfounded in science and misleading to young people.

Plimer labelled Roberts "a new creationist on the block" and declared that, as a university professor, he has "duties and responsibilities to the people [at large] who fund me".

Plimer studied the site near Mount Ararat in 1994 with Fasold, who was then still an Ark believer, and was recorded by television crews and magazine journalists. Plimer rejected Roberts' claims that "petrified wood", "rivets", "slag" and "drogue" (anchor stones) were common to the site, and said there was no evidence for "metallic" material, "uplift" following an earthquake or a "Great Flood". Plimer said the "mud" covering much of the structure is modern.

In evidence, Plimer said that a Turkish geophysicist from Ataturk University, Salih Bayraktutan, who has virtual control over the site, had prevented any excavations by Plimer, saying he "supported the views of Christian fundamentalists that this is the site of Noah's Ark".

But, according to Plimer, Bayraktutan said he didn't believe in Noah's Ark and that this was his equivalent of Loch Ness, adding "I'm sorry. This is the only way I can fund my research". Plimer has reported him to the rector of his university.

Fasold had depended heavily on Bayraktutan's information during several visits to the site and for a book he had written. Outside the court, Fasold said this was the first time he had heard of Bayraktutan's statement, but it explained how he had been misled for so long.

In evidence, Fasold said he was misled by John Baumgardner, a geophysicist at Los Alamos National Laboratory, New Mexico, who visited the site with him in 1986 and claimed his tests confirmed the authenticity of the remains. Fasold said that when he found last year that Baumgardner is a "creation scientist", his faith in the site collapsed.

As Roberts' barristers found difficulty in handling scientific evidence, the judge ensured the court was treated to lessons in Karl Popper's theory that science advances by successive falsifications, Lamarckian inheritance, Darwinian evolution and academic credentials.

Radojev tried to pin Plimer to a yes/no answer on the argument by creationists that evolution is unproven "theory" and not "fact". Plimer countered by repeating, until his interlocutor gave up, that evolution is "a process" drawing on interdisciplinary science. 